\title{
Literature review on tobacco smoking in Poland from 1960 to 2020. Bibliographic summary
}

\author{
Katarzyna Połtyn-Zaradna', Katarzyna Zatońska', Kinga Janik-Koncewicz², Zuzanna Stępnicka', \\ Alicja Basiak-Rasała', Witold Zatoński²
}

${ }^{1}$ Chair and Department of Social Medicine, Wrocław Medical University, Poland

2Institute - European Observatory of Health Inequalities, Calisia University, Kalisz, Poland

\begin{abstract}
Objectives: The tobacco epidemic is a constant threat and a challenge for public health worldwide. The aim of the presented review was to prepare a bibliographic analysis of literature on tobacco smoking in Poland from 1960 to 2020 and to present a comprehensive summary of available literature on the topic. Material and methods: We have undertaken a comprehensive electronic literature search of articles published between 1960 and 2020. Firstly, the PubMed and Web of Science databases were used to generate relevant publications. All articles with the terms "tobacco" or "cigarette" and "smoking" and "Poland" published in English or Polish language were included in the literature collection process. Moreover, we employed a search from Polish resources (mainly Główna Biblioteka Lekarska - GBL). Finally, to expand the generated literature a hand search was undertaken to collect publications available only in paper form, especially those published in the 1960s, 1970s, and 1980s.

Results: A total of 230 articles were included in the final analysis. The data collected included primary research articles (original papers, reviews), as well as other research documentation such as survey commentary reports, materials from conferences, and statistical reports. Records of smoking history and various analyses of its effects in Poland had been collected from the year 1960 to 2020.

Conclusions: Poland is one of the few countries that has closely monitored the prevalence of tobacco smoking in the population since the 1960s. The presented literature review gives a unique insight into patterns and trends of smoking over the years.
\end{abstract}

KEY WORDS: tobacco smoking, Poland, bibliographic summary.

ADDRESS FOR CORRESPONDENCE: Katarzyna Połtyn-Zaradna, Chair and Department of Social Medicine, Wrocław Medical University, 44 O. Bujwida St., 50-345 Wrocław, e-mail: katarzyna.poltyn-zaradna@umed.wroc.pl

\section{INTRODUCTION}

The tobacco epidemic is a constant threat and a challenge for public health worldwide. It is estimated that tobacco smoking is responsible for about 8 million deaths annually, with approximately 1 million deaths being due to second-hand exposure to tobacco smoke [1]. Besides alcohol consumption, tobacco smoking is one of the most important behavioural factors shaping the health of the Polish population. Poland has been monitoring the prevalence of tobacco smoking in the population since the 1960 s. This makes Poland a very interesting subject to study in order to analyse attitudes and behaviours towards tobacco smoking over the decades. In 1976 in Poland, approximately 10.5 million adult men (a shocking percentage of $73 \%$ ) were current smokers [2-4]. Until 1990 the prevalence of tobacco smoking in men decreased.

The aim of the presented review was to prepare a bibliographic analysis of literature on tobacco smoking in Poland from 1960 to 2020 and to present a comprehensive summary of available literature on the topic. This substantial collection of data can serve as a base for 
many interesting kinds of research not only in the science field but also in economics, sociology, politics, and other social sciences.

\section{MATERIAL AND METHODS}

In order to extract all the relevant articles available since 1960, a comprehensive electronic literature search was undertaken. The area of focus for the articles was an overview of smoking behaviour in youths and adults in Poland. Firstly, the PubMed and Web of Science databases were used to generate relevant publications. Thus, all articles with the terms "tobacco" or "cigarette" and "smoking" and "Poland" published in English or Polish language were included in the literature collection process. However, there were a limited number of articles generated from this search. One of the reasons might be that our area of interest is quite niche, and researchers who are interested in such discoveries are Poles, so a lot of the literature might not be translated into English. Therefore, we employed a search from Polish resources, in order to increase the bibliography. The main source thus became the Polish Medical Library (Główna Biblioteka Lekarska - GBL). Finally, to expand the generated literature a hand search was undertaken to collect publications available only in paper form, especially those published in the 1960s, 1970s, and 1980s.

\section{RESULTS}

Taken together, the PubMed, Web of Science, GBL, and Internet searches were undertaken to collect all the relevant literature about smoking behaviours in Poland. A total of 230 articles were included in the final analysis. The full list of the collected literature is presented in Supplement 1.

The data collected included primary research articles (original papers, reviews), as well as other research documentation such as survey commentary reports, materials from conferences, and statistical reports. Records of smoking history and various analyses of its effects in Poland had been collected from the year 1960 to 2020. Between 1960 and 2000, the main source of data on Poles' smoking habits came from the oldest research institute in Poland - the Public Opinion Research Centre (Ośrodek Badania Opinii Publicznej - OBOP). There had been 18 reports released over the years with the highest frequency released between 1994 and 2000 (a total of 11 reports).

After Poland joined the EU in 2004, few independent research groups had published data on smoking behaviours in Poland. These include the Multi-centre National Population Health Examination Survey (WOBASZ), Global Adult Tobacco Survey (GATS), Global Youth Tobacco Survey (GYTS), Polish-Norwegian Study (PONS), Prospective Urban Rural Epidemiology study (PURE), and European Regulatory Science on Tobacco: Policy implementation to reduce lung diseases (EUREST-PLUS). Most of these studies analysed were conducted on relatively large samples of the population. In total, 60 publications had been collected, with the first data published from the WOBASZ study in 2005. Finally, 6 reports from the World Health Organisation (WHO) were recorded. The publications were quite consistent, appearing in the years: 1994, 2004, 2009 (two publications appeared that year), 2010, and 2017.

In summary, many records on Poles' smoking behaviour had been collected over the last 6 decades. The $\mathrm{OBOP}$ was responsible for reports from studies conducted annually since 1974. Additionally, since the beginning of the 2000s, many additional studies had been published. The source of records on smoking behaviours was more diversified. Moreover, WHO data contributed to the diversity of the statistical data. Finally, the increase in the number and diversity of publications over the years might be explained by the increasing awareness of smoking health problems. The literature collected regarding smoking behaviour among Poles had been reported by various authors. Most of the researchers who contributed to this wide collection of data on smoking in Poland are Polish researchers, with the leading researchers being Witold Zatoński and Krzysztof Przewoźniak. However, there are also publications of international research groups as well as collaborative works between Polish and international scientists.

Taken together, the data on smoking behaviour in Poland had been widely discussed over the last decades. The interest in the field was probably attributed to Poland's phenomenal history of tobacco consumption. In the 1980s it was one the countries with the highest number of smokers, while after the 1990s Poles started to quit smoking on a massive scale, contributing to the astonishing decrease in smokers and leading to Poland having one of the most dynamic declines of smokers in the world [4].

\section{CONCLUSIONS}

Poland was one of the few countries closely monitoring the prevalence of tobacco smoking in the population since the 1960s. In the presented review, we conducted a comprehensive search of the literature on tobacco smoking prevalence in Poland. The manuscripts were drafted from both international and national databases.

The attitudes toward tobacco smoking changed dramatically in Poland over the years. The number of current smokers decreased since the 1970s [4]. There is an urgent need for further systematic and extensive monitoring of smoking prevalence, with a consistent protocol, because some of the national, regular surveys have been discontinued.

A presented literature review gives a unique insight into patterns and trends of smoking over the years.

\section{DISCLOSURE}

The authors report no conflict of interest. 


\section{References}

1. World Health Organization. Key facts on tobacco. Available online: https://www.who.int/news-room/fact-sheets/detail/tobacco (accessed: 3 December 2020)

2. Jokiel M. Zmiany w strukturze palenia tytoniu w Polsce w latach 1976, 1986 i 1990 [The changes in the structure of tobacco smoking in Poland in 1976, 1986 and 1990]. Przegl Epidemiol 1996, 50: 3 .

3. Zatoński WA, Zatoński M, Janik-Koncewicz K, et al. Hundred years of cigarette smoking in Poland: three phases of the tobacco epidemic. J Health Inequal 2017; 3 (2): 118-122.

4. Janik-Koncewicz K, Zatoński W, Zatońska K, et al. Cigarette smoking in Poland in 2019: the continuing decline in smoking prevalence. J Health Inequal 2020; 6 (2): 87-94.

\section{AUTHORS' CONTRIBUTION:}

KPZ made substantial contributions to conception and design, literature search, and drafting the manuscript. KZ made substantial contributions to revising the manuscript critically for important intellectual content. KJK made substantial contributions to drafting and revising the manuscript. ZS made contributions to literature search and drafting the manuscript. ABR made contributions to literature search. WZ made substantial contributions to conception and design and was involved in revising the manuscript critically for important intellectual content; manuscript guarantor. 


\section{Supplement 1. Literature on tobacco smoking in Poland - reference list}

1. Staszewski J. Smoking and cancer in Poland. Br J Cancer 1960; 14: 419-436

2. Ośrodek Badania Opinii Publicznej. Palić nie palić. Komunikat $\mathrm{z}$ badań OBOP [Smoke or not to smoke. A report from the Public Opinion Research Center]. OBOP, Warsaw 1974.

3. Todd GF. Cigarette consumption per adult of each sex in various countries. J Epidemiol Community Health 1978; 32 289-293.

4. Tyszko P. Palenie tytoniu przez ludność byłego powiatu pułtuskiego [Tobacco smoking in the population of the former Pułtusk district]. Zdrow Publiczne 1979; 90: 103-108.

5. Markiewicz K. Zagrożenie nikotynowe w Polsce [Nicotine risk in Poland]. Wiad Lek 1980; 33: 1771-1774.

6. Ośrodek Badania Opinii Publicznej. Palenie tytoniu w opinii społecznej. Komunikat $\mathrm{z}$ badań OBOP [Public opinion on cigarette smoking. Report from the Public Opinion Research Center]. OBOP, Warsaw 1980

7. Gibiński K. Smoking cost in Poland. World Smoking Health 1980; 5 (1): 47.

8. Korsak A. Dziś przestaję palić [Today I stop smoking]. Państwowy Zakład Wydawnictw Lekarskich, Warsaw 1983.

9. Jokiel M. Struktura palenia tytoniu w Polsce [Characterisation of smoking in Poland]. Przegl Epidemiol 1983; 37 (3/4): 435-443.

10. Kaczmarczyk-Chałas K, Gdulewicz T, Szadkowska-Stańczyk I. Nawyk palenia tytoniu w środowisku lekarzy w Polsce [Smoking habits among Polish physicians]. Pol Tyg Lek 1983; 42: 1395-1398.

11. Oleś P. The extent of tobacco use in Poland. World Smoking Health 1983; 8 (2): 38-44.

12. Zatoński W. Częstość i rozkład palenia tytoniu w Polsce [Frequency and distribution of smoking in Poland]. Przegl Przeciwtytoniowy 1984; 1: 136.

13. Zatoński W. Palenie tytoniu a zdrowie psychiczne i fizyczne Polaków [Cigarette smoking and the physical and mental health among Poles]. Przegl Przeciwtytoniowy 1984; 1: 16.

14. Pikiewicz K, Kuc K, Morgenstern W, et al. Częstość występowania nałogu palenia papierosów w populacji mężczyzn 8 zakładów przemysłowych Wrocławia [The cigarette smoking addiction prevalence in the male population of 8 industrial plants in Wroclaw]. Przegl Lek 1985; 42 (6): 528-531.

15. Szeszenia-Dąbrowska N, Kubasiewicz M. Rozpowszechnienie nałogu palenia papierosów wśród pracowników przemysłu włókienniczego w Łodzi [Cigarette smoking prevalence among textile industry workers in Łódź]. Zdrow Publiczne 1985; 96 (8): 380-382.

16. Zatoński W. Kształtowanie postaw wobec palenia tytoniu w PRL. Działalność społeczna [Development of attitudes towards smoking in Polish People's Republic. Social activities]. Zdrow Publiczne 1985; 8: 372.
17. Piwowarska-Pościk L. Nawyk palenia tytoniu wśród pracowników wybranych zakładów przemysłu lekkiego [Smoking habits among workers in selected light industrial plants]. Przegl Przeciwtytoniowy 1986; 3: 52-66.

18. Zatoński W, Przewoźniak K, Gottesman K. Zakres i następstwa zdrowotne palenia tytoniu $\mathrm{w}$ Polsce [Scope and health consequences of smoking in Poland]. In: Alkohol, narkotyki,tytoń. Skutki demograficzne w Polsce [Alcohol, drugs, tobacco. The demographic consequences in Poland]. Strzelecki Z. PAX, Warsaw 1986; 169-200.

19. Zajączkowski S. Zanim zapalisz przeczytaj [Read before you start]. Wydawnictwo Znaki Czasu, Warsaw 1987.

20. Zatoński W, Gottesman K, Przewoźniak K. Palenie tytoniu a umieralność na nowotwory złośliwe w Polsce [Tobacco smoking and cancer mortality in Poland]. Pneumonol Pol 1987; 7-8: 357-361.

21. Zatoński W, Przewoźniak K. Zawartość substancji szkodliwych w polskich papierosach w 1985 roku. [The content of harmful substances in Polish cigarettes in 1985]. Zdrow Publiczne 1988; 3: 145-150.

22. Zatoński W, Gottesman K, Przewoźniak K. Częstość palenia tytoniu w Polsce w 1985 roku [Tobacco smoking in Poland in 1985]. Zdrow Publiczne 1988; 3: 151-156.

23. Zatoński W, Becker N. Atlas of cancer mortality in Poland 1975-1979. Springer-Verlag, Berlin 1988.

24. Chabros E, Rywik S, Wągrowska H. Występowanie nałogu palenia papierosów u mężczyzn w wieku 40-59 lat z warszawskich zakładów pracy [The cigarette smoking addiction among men aged 40-59 from Warsaw workplaces]. Zdrow Publiczne 1988; 99(10): 504-510.

25. Przewoźniak K, Gottesman K, Kuta M, Zatoński W. Palenie tytoniu w Polsce w 1987 roku [Tobacco smoking in Poland in 1987]. Zdrow Publiczne 1990; 101: 553-559.

26. Stolarska B, Przewoźniak K. Daleko od Europy [Far from Europe]. Magazyn Medyczny 1991; 2 (1): 4-5.

27. Zatoński W, Becher H, Lissowska J, et al. Tobacco, alcohol, and diet in the etiology of laryngeal cancer: a population-based case-control study. Cancer Causes Control 1991; 2: 3-10.

28. Przewoźniak K. Postawy Polaków wobec palenia tytoniu [Attitudes towards tobacco smoking in Poland]. Świat Medycyny $1991 ; 3: 25$.

29. Pierce JP. Progress and problems in international public health efforts to reduce tobacco usage. Annu Rev Public Health 1991; 12: 383-400

30. Peto R, Lopez A, Boreham J, et al. Mortality from tobacco in developed countries: indirect estimates from national vital statistics. Lancet 1992; 339: 1268-1278.

31. Ośrodek Badania Opinii Publicznej. Palenie tytoniu. Komunikat $\mathrm{z}$ badań OBOP [Tobacco smoking. Report from the Public Opinion Research Center]. OBOP, Warsaw 1992. 
32. Ośrodek Badania Opinii Publicznej. „Rzuć palenie razem z nami" - społeczny rezonans i skuteczność akcji promującej niepalenie. Komunikat z badań OBOP [„Quit smoking with us" - social resonance and effectiveness of the campaign to promote the smoking cessation. Report from the Public Opinion Research Center]. OBOP, Warsaw 1992.

33. Andrejew-Frączek D. Rozpowszechnienie używania tytoniu w Polsce i jego skutki [Prevalence of tobacco use in Poland and its effects]. Kancelaria Sejmu. Biuro Studiów i Ekspertyz. Zespół Opinii Społeczno-Ekonomicznych, Warsaw 1992.

34. Becher H, Zatoński W, Jockel KH. Passive smoking study in Germany and Poland: comparison of exposure levels, sources of exposure, validity and perception. Epidemiology 1992; 3 (6): 509-514.

35. Zatoński W, Przewoźniak K (eds). Zdrowotne następstwa palenia tytoniu w Polsce [Health consequences of tobacco smoking in Poland]. Ariel, Warsaw 1992.

36. Grzonkowski S, Jasiński B. Uwarunkowania zmian w nałogu palenia papierosów przez populację [Conditions for changes in the population's smoking habits]. Zdrow Publiczne 1992; 103 (2): 80-87.

37. Zatoński W, Przewoźniak K. Palenie tytoniu a stan zdrowia ludności w Polsce [Tobacco smoking and population's health in Poland]. Przegl Epidemiol 1992; 38: 53-57.

38. Ośrodek Badania Opinii Publicznej. Palenie tytoniu. Komunikat $\mathrm{z}$ badań OBOP [Tobacco smoking. Report from the Public Opinion Research Center]. OBOP, Warsaw 1993.

39. Doll R, Peto R, Bjartveit K, et al. Tobacco and death in Eastern Europe. In: Cancer prevention in Europe. Bodmer W, Zaridze D. Organization of European Cancer Institutes, London 1993; 71-97.

40. Zatoński W, Pukkala E, Didkowska J, et al. Atlas umieralności na nowotwory złośliwe w Polsce w latach 1986-1990 [Atlas of cancer mortality in Poland in 1986-1990]. Interspar, Warsaw 1993.

41. Przewoźniak K, Zatoński W. Tobacco smoking in Poland in the years 1923-1987. Polish Population Review 1993; 3: 103-124.

42. Zatoński W, Przewoźniak K. Tytoń a zdrowie. Palenie tytoniu czy zdrowie - dylemat współczesnej cywilizacji [Tobacco and health. Tobacco smoking or health - the dilemma of modern civilisation]. In Promocja Zdrowia. Karski JB, Słońska Z, Wasilewski BW (eds). Sanmedia, Warsaw 1994: 263-280.

43. Murray C, Lopez A. Global and regional cause-of-death patterns in 1990. Bulletin on the World Health Organization 1994; 72 (3): 447-480.

44. Ośrodek Badania Opinii Publicznej. Palenie tytoniu. Komunikat $\mathrm{z}$ badań OBOP [Tobacco smoking. Report from the Public Opinion Research Center]. OBOP, Warsaw 1994.

45. Ośrodek Badania Opinii Publicznej. Palenie tytoniu II. Komunikat $\mathrm{z}$ badań OBOP [Tobacco smoking II. Report from the Public Opinion Research Center]. OBOP, Warsaw 1994.

46. Patel T. Eastern Europe heads for smoking catastrophe. New Scientist 1994; Available from: https://www.newscientist.com/ article/mg14419481-400-eastern-europe-heads-for-smokingcatastrophe/ (accessed: 10 November 2020).
47. Ośrodek Badania Opinii Publicznej. Społeczny odbiór akcji „Rzuć palenie razem z nami. Komunikat z badań OBOP [Social reception of the "Quit smoking with us" campaign. Report from the Public Opinion Research Center]. OBOP, Warsaw 1994.

48. Ośrodek Badania Opinii Publicznej. Palenie tytoniu. Komunika z badań OBOP [Tobacco smoking. Report from the Public Opinion Research Center]. OBOP, Warsaw 1995.

49. Hertzmann C. Environment and health in Central and Eastern Europe. World Bank, Washington DC 1995.

50. Zatoński W. Stan zdrowia Polaków a palenie tytoniu [Health of Poles and smoking]. In: Palenie tytoniu a zdrowie [Tobacco smoking and health]. Milanowski J, Błędowski J. Instytut Medycyny Wsi, Lublin 1995; 11-22.

51. Ustawa $\mathrm{z}$ dnia 9 listopada 1995 r. o ochronie zdrowia przed następstwami używania tytoniu i wyrobów tytoniowych (Dz.U. z 1996 r. Nr 10 poz. 55) [Act on health protection againts the consequences of consumption of tobacco and tobacco products, 1996, no 10, pos. 55].

52. Zatoński W. The health of the Polish population. Public Health Rev 1995; 23: 139-156.

53. Zatoński W. Stan zdrowia Polaków a palenie tytoniu [Health of Poles and tobacco smoking]. Biuletyn Informacyjny Centrum Onkologii-Instytut 1995; 2-3: 1-22.

54. Riboli E, Haley NJ, Tredaniel J, et al. Misclassification of smoking status among women in relation to exposure to environmental tobacco smoke. Eur Resp J 1995; 8: 285-290.

55. Ośrodek Badania Opinii Publicznej. Rzuć palenie razem z nami. Komunikat z badań OBOP [Quit smoking with us. Report from the Public Opinion Research Center]. OBOP, Warsaw 1995.

56. Ośrodek Badania Opinii Publicznej. Jakie zachowania potępiamy? Komunikat z badań OBOP [What behaviour we condemn? Report from the Public Opinion Research Center]. OBOP, Warsaw 1995.

57. Kubik AK, Parkin DM, Plesko I, et al. Patterns of cigarette sales and lung cancer mortality in some central and eastern European countries, 1960-1989. Cancer 1995; 75 (10): 24522460.

58. Connolly GN. Tobacco, trade and Eastern Europe. In: Tobacco and health. Slama K. Plenum Press, New York 1995.

59. Zatoński W. An overview of the challenges in tobacco problems in Central and Eastern Europe. In: Tobacco and Health. Slama K. Plenum Press, New York 1995; 281-283.

60. Zatoński W, Smas M, Tyczyński J, et al. Atlas of cancer mortality in Central Europe. IARC Scientific Publications 134. International Agency for Research on Cancer, Lyon 1995.

61. Goldstein, Preker, Adeyi et al. Trends in health status, services, and finance: the transition in Central and Eastern Europe. World Bank Technical Paper No. 341. World Bank, Washington 1996.

62. Ośrodek Badania Opinii Publicznej. Opinie Polaków o paleniu papierosów. Komunikat $\mathrm{z}$ badań OBOP [The opinions of Poles about smoking cigarettes. Report from Public Opinion Research Center]. OBOP, Warsaw 1996. 
63. Zatoński W, Przewoźniak K. Palenie tytoniu w Polsce: postawy, następstwa zdrowotne i profilaktyka [Tobacco smoking in Poland: attitudes, health consequences and prevention]. Centrum Onkologii-Instytut im. Marii Skłodowskiej-Curie, Warsaw 1996.

64. Boyle P, Maisonneuve P, Bas Bueno De Mesquita H, et al. Cigarette smoking and pancreas cancer: a case-control study of the SEARCH programme of the IARC. Int J Cancer 1996; 67 (1): 63-71.

65. Ustawa z dnia 5 grudnia 1996 r. Rozporządzenie Ministra Zdrowia i Opieki Społecznej (Dz.U. z 1996 r. Nr 146) [Ordinance of Minister for Health and Social Welfare, 1996, no 146].

66. Fagerström KO, Kunze M, Schoberberger R, et al. Nicotine dependence versus smoking prevalence: comparisons among countries and categories of smokers. Tob Control 1996; 5 (1): 52-56.

67. Zatoński W. Health status and tobacco smoking in Eastern European countries. Eur J Cancer Prev 1996; 5 (2): 135-136.

68. Jokiel M. Zmiany w strukturze palenia tytoniu w Polsce w latach 1976, 1986 i 1990 [Changes in the characterisation of smoking in Poland in years 1976, 1986 and 1990]. Przegl Epidemiol 1996; 50: 3.

69. Zatoński W, Boyle P. Commentary. Health transformations in Poland after 1988. J Epidemiol Biostat 1996; 4: 183-197.

70. Ośrodek Badania Opinii Publicznej. „Palenie tytoniu” i odbiór akcji społecznej „Rzuć palenie razem z nami”. Wyniki badania OBOP [Tobacco smoking and the outcome of the "Quit smoking with us" campaign. Results tables from the Public Opinion Research Center]. OBOP, Warsaw 1997.

71. Paniccia R. Economic shocks, impoverishment and poverty-related mortality during the Eastern European transition. Working papers 126. The United Nations University/World Institute for Development Economics Research, Tokyo 1997.

72. Ośrodek Badania Opinii Publicznej. Rzuć palenie razem z nami. Komunikat z badań OBOP [Quit smoking with us. Report from the Public Opinion Research Center]. OBOP, Warsaw 1997.

73. Doll R. Uncovering the effects of smoking: historical perspective. Statistical Methods in Medical Research 1998; 7: 87-117.

74. McKee M, Zatoński W. How the cardiovascular burden of illness is changing in eastern Europe. Evid Based Cardiovasc Med 1998; 2 (2): 39-41.

75. Zatoński WA, McMichael AJ, Powles JW. Ecological study of reasons for sharp decline in mortality from ischaemic hearth disease in Poland since 1991. BMJ 1998; 316 (7137): 10471051.

76. Mazur J, Woynarowska B. Palenie tytoniu wśród młodzieży szkolnej w Polsce i w innych krajach w latach 1990-1998 [Smoking among schoolchildren in Poland and other countries in 1990-1998]. Zdrow Publiczne 1999; 9: 312-319.

77. Ośrodek Badania Opinii Publicznej. Palenie papierosów. Wyniki sondażu OBOP [Tobacco smoking. Report from the survey conducted by the Public Opinion Research Center]. OBOP, Warsaw 1999.

78. Zatoński W. The dynamics of mortality in Poland. In: Health and mortality issues of global concern. Department of Eco- nomic and Social Affairs Population Division in collaboration with Population and Family Study Centre (CBGS) and Flemish Scientific Institute (Brussels). United Nations, New York 1999; 227-261.

79. Jaworski JM, Linke-Drzyżdżyk D. (eds.). Akcja rzuć palenie razem z nami 1999 [Let's stop smoking together, the Great Polish Smoke-out 1999]. Centrum Onkologii - Instytut im. Marii Skłodowskiej-Curie, Warsaw 1999.

80. Chow W-H, Swanson CA, Lissowska J, et al. Risk of stomach cancer in relation to consumption of cigarettes, alcohol, tea and coffee in Warsaw, Poland. Int J Cancer 1999; 81 (6): 871-876.

81. Didkowska J, Wojciechowska U, Zatoński W. Spożycie tytoniu w Polsce w latach 1923-1995 [Tobacco consumption in Poland between 1923 and 1995]. In:Palenie tytoniu w Polsce: postawy, następstwa zdrowotne i profilaktyka [Smoking in Poland: attitudes, health consequences and prevention]. Zatoński W, Przewoźniak K (eds). Centrum Onkologii-Instytut im. M. Skłodowskiej-Curie, Warsaw 1999; 111-112.

82. Ośrodek Badania Opinii Publicznej. Palenie papierosów. Wyniki sondażu OBOP [Tobacco smoking.Report from the Public Opinion Research Center]. OBOP, Warsaw 2000.

83. Boyle P, Gandini S, Robertson Ch, et al. Characteristics of smokers' attitudes towards stopping - Survey of 10,295 smokers in representative samples from 17 European countries. Eur J Public Health 2000; 10 (Suppl 3): 5-14.

84. Peto R, Darby s, Deo H, et al. Smoking, smoking cessation and lung cancer in the UK since 1950: combination of national statistics with two case-control studies. BMJ 2000; 321: 323-329.

85. Zatoński W, Harville E. Tobacco control in Poland. Eurohealth 2000; 6 (1): 13-15.

86. Fagerström K, Boyle P, Kunze M, et al. The anti-smoking climate in EU countries and Poland. Lung Cancer 2001; 32 (1): 1-5.

87. The Global Youth Survey Collaborative Group (Przewoźniak K, Zatoński W). Special report - tobacco use among youth: a cross country comparison. Tob Control 2002; 11: 252-270.

88. Gilmore A, Zatoński W. Free trade versus the protection of health - how will EU accession influence tobacco control in Poland? Eurohealth 2002; 8 (4): 31-33.

89. Zatoński W. Decreasing smoking in Poland: The importance of a comprehensive governmental policy. J Clin Psychiatry 2003; 18 (1): 74-82

90. Zatonski W. Democracy and health: tobacco control in Poland. In: Tobacco Control Policy: strategies, successes and setbacks. de Beyer J, Waverly Brigden L. World Bank, Washington 2003: 97-120.

91. Zatoński W. Droga do zdrowia. Historia przeciwdziałania chorób odtytoniowych w Polsce [Pathway to health. History of tobacco control in Poland]. Fundacja "Promocja Zdrowia", Warsaw 2004.

92. Zatoński W. Tobacco smoking in central European countries: Poland. In: Tobacco and public health: science and policy. Boyle P, Gray N, Henningfield J, et al. Oxford University Press, New York 2004: 235-252.

93. Blanke DD, de Costa e Silva V. Tools for advancing tobacco control in the $21^{\text {st }}$ century. Tobacco control legislation: 
an introductory guide. World Health Organization, Geneva 2004.

94. Gilmore AB, Österberg E, Heloma A, et al. Free trade versus protection of health: the examples of alcohol and tobacco. In: Health policy and European Union enlargement. McKee M, MacLehose L, Nolte E. Open University Press 2004: 198-224.

95. Jaworski JM, Przewoźniak K, Zatoński W. Rzuć palenie razem z nami [Let's stop smoking together]. Fundacja „Promocja Zdrowia”, Warsaw 2004.

96. ASPECT Consortium. Tobacco or health in the European Union. Past, present and future. Office for Official Publications of the European Communities, Luxembourg 2004.

97. Zatoński W, Przewoźniak K. Cel operacyjny nr 3: Zmniejszenie rozpowszechniania palenia tytoniu [Operational objective No 3: Reduce the prevalence of smoking]. In: Monitoring oczekiwanych efektów realizacji Narodowego Programu Zdrowia [Monitoring the expected effects of the implementation of the National Health Programme]. Goryński P, Wojtyniak B, Kuszewski K. Państwowy Zakład Higieny, Warsaw 2004.

98. Polakowska M, Piotrowski W, Tykarski A, et al. Nałóg palenia tytoniu w populacji polskiej. Wyniki programu WOBASZ [Smoking addiction in the Polish population. Results of the WOBASZ study]. Kardiol Pol 2005; 63 (Suppl 4): 626-631.

99. Rodryg R, Didkowska J, Wojciechowska U, et al. Palenie tytoniu $\mathrm{w}$ Wielkopolsce $\mathrm{w}$ końcu XX wieku [Smoking in Wielkopolska region in the end of the 20th century]. Pneumonol Alergol Pol 2005; 73 (2): 128-134.

100. Blackford AL, Yang G, Hernandez-Avila M, et al. Cotinine concentration in smokers from different countries: relationship with amount smoked and cigarette type. Cancer Epidemiol Biomarkers Prev 2006; 15: 1799-1804.

101. Florek M. Palenie papierosów i spożycie alkoholu wśród ludności wiejskiej, a jej opinie na temat profilaktyki zdrowotnej [Cigarette smoking and alcohol consumption among the rural population and their views on health prevention]. Med Ogólna $2006 ; 12(1 / 2): 27-36$.

102. Jha P, Peto R, Zatoński W, et al. Social inequalities in male mortality, and in male mortality from smoking: indirect estimations from national death rates in England and Wales, Poland, and North America. Lancet 2006; 368: 367-370.

103. Soerjomataram I, de Vries E, Pukkala E, et al. Excess of cancers in Europe: a study of eleven major cancers amenable to lifestyle change. Int J Cancer 2007; 120: 1336-1343.

104. West R, Zatoński W, Przewoźniak K, et al. Can we trust national smoking prevalence figures? Discrepancies between biochemically assessed and self-reported smoking rates in three countries. Cancer Epidemiol Biomarkers Prev 2007; 16 (4): 820-822.

105. Zatońska K, Waszkiewicz L, Połtyn-Zaradna K. Ocena stopnia otyłości oraz postaw wobec palenia tytoniu u kobiet i mężczyzn zamieszkałych na Dolnym Śląsku [Assessment of obesity and attitudes towards smoking in women and men living in Lower Silesia]. Probl Hig Epidemiol 2007; 88 (2): 171-174.

106. Zatoński W. Jak rzucić palenie [How to stop smoking]. Fundacja „Promocja Zdrowia”, Warsaw 2007.
107. Zatoński W. Konsensus dotyczący rozpoznania i leczenia zespołu uzależnienia od tytoniu [Consensus on diagnosis and treatment of tobacco dependence]. Wydawnictwo Medycyna Praktyczna, Kraków 2007.

108. Ośrodek Badania Opinii Publicznej. Zdrowe życie w Polsce. Komunikat $\mathrm{z}$ badań TNSOBOP K.56/08 [Healthy life in Poland. Communication from TNSOBOP study K.56/08]. Warsaw 2008.

109. Gerstenkorn A, Drygas W, Suwała M. Wpływ cech społeczno-demograficznych na palenie tytoniu w starszym wieku [The influence of socio-demographic characteristics on smoking in old age]. 9th National Scientific Conference "Tobacco and Health - Smoke is a Poison. Przegl Lek 2008; 65 (10): 617-620.

110. Kaleta D, Polańska K, Kwaśniewska M, et al. Czynniki warunkujące palenie tytoniu wśród osób dorosłych - wyniki badania WOBASZ w województwie łódzkim [Factors determining smoking among adults - results of the WOBASZ survey in the Łódź Province]. Med Praktyczna 2008; 59 (2): 143-148.

111. Thyrian JR, Panagiotakos DB, Polychronopoulos E, et al. Relationship between smokers motivation to quit and intensity of tobacco control at the population level: a comparison of five European countries. BMC Public Health 2008; 8: 2.

112. Zatoński $\mathrm{W}$ and the HEM Project team. Closing the health gap in European Union. Cancer Center and Institute of Oncology, Warsaw 2008.

113. Zatoński W, Przewoźniak K. Działania ograniczające palenie w Polsce - dokonania i plany na przyszłość [Smoking control measures in Poland - achievements and future plans]. Onkol Prakt Klin 2008; 4 (Suppl B): 10.

114. Kaleta D, Makowiec-Dabrowska T, Polanska K, et al. Palenie tytoniu i inne negatywne zachowania zdrowotne wśród osób czynnych zawodowo [Smoking and other negative health behaviours among the working population]. Med Pracy 2009; 60 (1): 7-14.

115. Mańczuk M, Zatoński W. Palenie tytoniu w Polsce na tle krajów Unii Europejskiej [Smoking in Poland compared with European Union countries]. Zeszyty Naukowe Ochrony Zdrowia Zdrowie Publiczne i Zarządzanie 2009; 7 (2): 20-28.

116. Przewoźniak K, Szlaza J, Gumkowski J, et al. Trendy codziennego palenia papierosów w Polsce w populacji kobiet w wieku prokreacyjnym w latach 1974-2004 [Trends in daily cigarette smoking in Poland in the population of women of reproductive age between 1974 and 2004]. Zeszyty Naukowe Ochrony Zdrowia Zdrowie Publiczne i Zarządzanie 2009; 7 (2): 36-43.

117. World Health Organization. Stan zagrożenia epidemią palenia tytoniu w Polsce [The state of emergency of the smoking epidemic in Poland]. WHO, Geneva 2009.

118. Suwała M, Drygas W, Gwizdała K. Palenie tytoniu w małych gminach województwa łódzkiego [Smoking in small municipalities in the Łódź Province]. 10 Ogólnopolska Konferencja Naukowa pt. Tytoń a zdrowie - Polska na tle Europy [ $10^{\text {th }}$ Polish National Scientific Conference „Tobacco and Health Poland in Europe]. Przegl Lek 2009: 66 (10): 760-764.

119. World Health Organization. The current status of the tobacco epidemic in Poland. WHO, Geneva 2009. 
120. Zatoński W, Przewoźniak K, Sulkowska U, et al. Palenie tytoniu $\mathrm{w}$ populacji mężczyzn i kobiet w Polsce w latach 1974-2004 [Smoking in the population of men and women in Poland between 1974-2004]. Zeszyty Naukowe Ochrony Zdrowia Zdrowie Publiczne i Zarządzanie 2009; 7 (2): 4-11.

121. Hashibe M, Brennan P, Chuang S, et al. Interaction between tobacco and alcohol use the risk of head and neck cancer: pooled analysis in the INHANCE consortium. Cancer Epidemiol Biomarkers Prev 2009; 18: 541-550.

122. Jóźwiak P, Wysocki J. Motywacje osób uzależnionych od nikotyny do zaprzestania palenia [Motivation behind nicotine addicts to stop smoking].10 Ogólnopolska Konferencja Naukowa pt. Tytoń a zdrowie - Polska na tle Europy [10 $10^{\text {th }}$ Polish National Scientific Conference „Tobacco and Health - Poland in Europe]. Przegl Lek 2009; 66 (10): 777-782.

123. Zatoński W, Mańczuk M. Tobacco smoking and tobacco-related harm in the European Union with special attention to the new EU member states. In: Tobacco Science, policy, and public health. Boyle P, Gray N, Henningfield J, et al. Oxford University Press, New York 2010; 221-240.

124. Ministry of Health of Poland. Global adult tobacco survey. Poland 2009-2010. Ministry of Health, Warsaw 2010.

125. Panasiuk L, Mierzecki A, Wdowiak L, et al. Prevalence of cigarette smoking among adult population in eastern Poland. Ann Agric Environ Med 2010; 17: 133-138.

126. Szymocha M, Bryła M, Maniecka-Bryła I. Palenie tytoniu a rodzaj wykonywanej pracy - badania populacji osób pracujących na terenie województwa świętokrzyskiego [Smoking and the type of work performed - research on the population of people working in the Świętokrzyskie Voivodeship]. 11 Ogólnopolska Konferencja Naukowa pt. Tytoń a zdrowie. Tyton - skutki zdrowotne i społeczne $\left[11^{\text {th }}\right.$ Polish National Scientific Conference on Tobacco and Health. Tobacco - health and social consequences]. Przegl Lek 2010; 67 (10): 1004-1007.

127. Thyrian JR, Demosthenes B, Polychronopulos E, et al. The exposure to environmental tobacco smoke and attitudes towards tobacco control measures - a comparison of 5 European Countries. Cent Eur J Public Health 2010; 18 (2): 87-92.

128. Ośrodek Badania Opinii Publicznej. Walka $\mathrm{z}$ dymem tytoniowym. Komunikat $\mathrm{z}$ badań TNSOBOP K.074/10 [Fight against tobacco smoke. Communication from TNSOBOP study K.074/10]. OBOP, Warsaw 2010.

129. Woitas-Ślubowska D, Hurnik E, Skarpańska-Stejnborn A. Correlates of smoking with socioeconomic status, leisure time physical activity and alcohol consumption among Polish adults from randomly selected regions. Cent Eur J Public Health 2010; 18 (4): 179-185.

130. Kwaśniewska M, Kaczmarczyk-Chałasa K, Pikała Broda M, et al. Socio-demographic and lifestyle correlates of commuting activity in Poland. Preventive Medicine 2010; 50 (5-6): 257-261.

131. Thun MJ, Henley SJ. The great studies of smoking and disease in the twentieth century. In: Tobacco or health: a global status report. World Health Organization, Geneva 2010.

132. Anantharaman D, Marron M, Lagiou P, et al. Population attributable risk of tobacco and alcohol for upper aerodigestive tract cancer. Oral Oncology 2011; 47: 725-731.
133. Gacek M. Wybrane zachowania zdrowotne grupy kobiet w środowisku wiejskim i miejskim w świetle statusu socjoekonomicznego i stanu odżywienia [Selected health behaviour of a group of women in a rural and urban environment in the light of their socioeconomic and nutritional status]. Probl Hig Epidemiol 2011; 92 (2): 260-266.

134. Olsson AC, Gustavsson P, Zaridzre D. Lung cancer risk attributable to occupational exposures in a multicenter case-control study in Central and Eastern Europe. J Occup Environ Med 2011; 53: 1262-1267.

135. Przewoźniak K, Łobaszewski J, Cedzyńska M, et al. Cigarette smoking among a sample of PONS study subjects: preliminary assessment. Ann Agric Environ Med 2011; 18 (2): 215-220.

136. Rachtan J, Sokołowski A. Palenie tytoniu wśród kobiet powyżej 30. roku życia w Małopolsce [Smoking among women over 30 in Małopolska]. Pneumonol Alergol Pol 2011; 79 (1): 16-20.

137. Cakir B, Tas A, Sanver T.M, et al. Doctor's enquiry: an opportunity for promoting smoking cessation - findings from Global Adult Tobacco Surveys in Europe. Eur J Public Health 2012; 27 (5): 921-925.

138. Fronczak A, Polańska K,Bąk-Romaniszyn L, et al. Changes in smoking prevalence and exposure to environmental tobacco smoke among adults in Łódź, Poland. Ann Agric Environ Med 2012; 19 (4): 754-761.

139. Giovino GA, Mirza SA, Samet JM, et al. Tobacco use in 3 billion individuals from 16 countries: an analysis of nationally representative cross-sectional household surveys. Lancet 2012; 380: 668-679.

140. Goszczyńska E. Wyzwania stojące przed organizatorami działań antytytoniowych adresowanych do kobiet w Polsce [Challenges facing the organisers of anti-tobacco activities addressed to women in Poland]. Med Pracy 2012; 63 (4): 471-482.

141. Kaleta D, Makowiec-Dabrowska T, Dziankowska-Zaborszczyk E, et al. Determinants of heavy smoking: results from the Global Adult Tobacco Survey in Poland (2009-2010). Int J Occup Med Environ Health 2012; 25 (1): 66-79.

142. Kaleta D, Korytkowski P, Makowiec-Dabrowska T, et al. Predictors of long-term smoking cessation: results from the global adult tobacco survey in Poland (2009-2010). BMC Public Health 2012; 12: 1020.

143. Kaleta D, Makowiec-Dabrowska T, DziankowskaZaborszczyk E, et al. Prevalence and socio-demographic correlates of daily cigarette smoking in Poland: results from the Global Adult Tobacco Survey (2009-2010). Int J Occup Med Environ Health 2012; 25 (2): 126-136.

144. Kostova D, Chaloupka F, Yurekli A, et al. A cross-country study of cigarette prices and affordability: evidence from the Global Adult Tobacco Survey. Tob Control 2012; 23 (1): e3.

145. Palipudi KM, Gupta PC, Sinha DN, et al. Social determinants of health and tobacco use in thirteen low and middle income countries: evidence from Global Adult Tobacco Survey. PLoS One 2012; 7 (3): e33466.

146. Zatoński W, Bhala N. Changing trends of diseases in Eastern Europe: Closing the gap. Public Health 2012; 126 (3): 248-252. 
147. Zatoński W, Przewoźniak K, Sulkowska U, et al. Tobacco smoking in countries of the European Union. Ann Agric Environ Med 2012; 19 (2): 181-192.

148. Zatoński W, Zatoński M, Przewoźniak K. Health improvement in Poland is contingent on continued extensive tobacco control measures. Ann Agric Environ Med 2013; 20 (2): 405-411.

149. Kaleta D, Makowiec-Dąbrowska T, Dziankowska-Zaborszczyk E, et al. Predictors of smoking initiation - results from the Global Adult Tobacco Survey (GATS) in Poland 2009-2010. Ann Agric Environ Med 2013; 20 (4): 756-766.

150. Kaleta D, Korytkowski P, Makowiec-Dabrowska T. Palenie papierosów w populacji osób czynnych zawodowo [Cigarette smoking in the working population]. Medycyna Pracy 2013; 64 (3): 359-371.

151. Kanicka M, Poniatowski B, Charkiewicz A, et al. Spożycie papierosów w Polsce po wprowadzeniu Ustawy z dnia 9 listopada 1995 roku o ochronie zdrowia przed następstwami używania tytoniu i wyrobów tytoniowych [Cigarette consumption in Poland after the introduction of the Act of 9 November 1995 on health protection against the consequences of tobacco and tobacco products]. Hygeia Public Health 2013; 48 (3): 333-336.

152. King BA, Mirza SA, Babb SD, et al. A cross-country comparison of secondhand smoke exposure among adults: findings from the Global Adult Tobacco Survey (GATS). Tob Control 2013; 22 (4): e5.

153. Włodarczyk A, Raciborski F, Opoczyńska D, et al. Daily tobacco smoking patterns in rural and urban areas of Poland - the results of the GATS study. Ann Agric Environ Med 2013; 20 (3): 588-594.

154. Forey B, Hamling J, Hamling J, et al. International Smoking Statistics A collection of worldwide historical data Poland. P N Lee Statistics \& Computing Ltd., Sutton 2014.

155. Jassem J, Przewoźniak K, Zatoński W. Tobacco control in Poland - successes and challenges. Translational Lung Cancer Research 2014; 3 (5): 280-285.

156. Jóźwiak P, Wierzejska E, Szmagaj A, et al. Czynniki warunkujące palenie tytoniu w grupie osób po 45 roku życia [Smoking determinants among people over 45 years of age]. Przegl Lek 2014; 71 (11): 609-615.

157. Kaleta D, Usidame B, Dziankowska-Zaborszczyk E, et al. Prevalence and factors associated with hardcore smoking in Poland: Findings from the Global Adult Tobacco Survey (2009-2010). BMC Public Health 2014; 14: 583.

158. Ng M, Freeman MK, Fleming TD, et al. Smoking Prevalence and Cigarette Consumption in 187 Countries, 1980-2012. Journal of the American Medical Association 2014; 311 (2): 183-192.

159. Ross H, Kostova D, Stoklosa M, et al. The impact of cigarette excise taxes on smoking cessation rates from 1994 to 2010 in Poland, Russia, and Ukraine. Nicotine Tob Res 2014; 16 (Suppl 1): 37-43.

160. Główny Urząd Statystyczny. Zdrowie i zachowanie zdrowotne mieszkańców Polski w świetle Europejskiego Ankietowego
Badania Zdrowia (EHIS) 2014 r. [The health and health behaviour of Polish citizens in the light of the European Health Interview Survey (EHIS) 2014]. GUS, Warsaw 2015.

161. Zatoński W, Zatoński M. Cytisine versus nicotine for smoking cessation. NEJM 2015; 11 (372): 1072.

162. Kaleta D, Polańska K, Korytkowski P, et al. Patterns of nicotine dependence in four Eastern European countries. BMC Public Health 2015; 15: 1189.

163. Mbulo L, Palipudi KM, Nelson-Blutcher G, et al. The process of cessation among current tobacco smokers: a cross-sectional data analysis from 21 countries, Global Adult Tobacco Survey, 2009-2013. Prev Chronic Dis 2015; 12: 1-5.

164. European Commission. Attitudes of Europeans towards tobacco. Special Eurobarometer 429, May 2015. Available from: https://www.newscientist.com/article/mg14419481400 -eastern-europe-heads-for-smoking-catastrophe/ (accessed: 2 December 2020).

165. Zatoński WA, Zatoński M. Sytuacja zdrowotna [Health situation]. In: Dzieje medycyny w Polsce, tom 3. Lata 1944-1989. [History of Medicine in Poland, Volume 3, Years 1944-1989]. Noszczyk W. Wydawnictwo Lekarskie PZWL, Warsaw 2016.

166. Połtyn-Zaradna K, Basiak A, Zatońska K, et al. Prevalence of tobacco smoking among participants of PURE Poland study. J Health Inequal 2016; 2 (2): 142-147.

167. Sozańska B, Pearce N, Błaszczyk M, et al. Changes in the prevalence of cigarette smoking and quitting smoking determinants in adult inhabitants of rural areas in Poland between 2003 and 2013. Public Health 2016; 141: 178-184.

168. Zatoński M, Zatoński WA, Przewoźniak K, et al. The significance and impact of the Polish anti-tobacco law. J Health Inequal 2016; 2 (1): 32-35.

169. Zatoński M, Zatoński WA, Wojtyła A. Premature mortality: Europe's persisting Iron Curtain? J Health Inequal 2016; 2 (1): 3-6.

170. Zatoński M. Marking the 20th anniversary of the Polish Anti-tobacco Law. J Health Inequal 2016; 2 (2): 110.

171. Zatoński M. Poland's anti-tobacco advocacy - a historical outline. J Health Inequal 2016; 2 (1): 26-31.

172. Zatoński WA, Aaro LE, Samdal O, et al. Smoking- or nicotine-free generation, or both? What should be the public health priority? J Health Inequal 2016; 2 (2): 105-108.

173. Zatoński WA, Zatoński M. Democracy is healthier - health in Poland in the late 1980s and 1990s. J Health Inequal 2016; 2 (1): 17-24.

174. Zatoński WA, Zatoński M. Health in the Polish People's Republic. J Health Inequal 2016; 2 (1): 7-16.

175. Aaro LE, Mazur J, Zatoński WA, et al. Trends in smoking among Polish and Norwegian youth 1986-2014. J Health Inequal 2016; 2 (1): 44-51.

176. Chiosi JJ, Andes L, Asma S, et al. Warning about the harms of tobacco use in 22 countries: findings from a cross-sectional household survey. Tob Control 2016; 25 (4): 391-401.

177. Kaleta D, Wojtysiak P, Usidame B, et al. Heaviness of smoking among employed men and women in Poland. International J Occup Med Environ Health 2016; 29 (2): 1-18. 
178. Leon ME, Lugo A, Boffetta P, et al. Smokeless tobacco use in Sweden and other 17 European countries. Eur J Public Health 2016; 26 (5): 817-821.

179. Milcarz K, Makowiec-Dąbrowska T, Bak-Romaniszyn L, et al. Smoking patterns and smoking cessation willingness - a study among beneficiaries of government welfare assistance in Poland. Int J Environ Res Public Health 2017; 14: 131.

180. Polakowska M, Kaleta D, Piotrowski W, et al. Tobacco smoking in Poland in the years from 2003 to 2014. Multi-centre National Population Health Examination Survey (WOBASZ). Polish Arch Int Med 2017; 127 (2): 91-99.

181. Reitsma MB, Fullman N, Ng M, et al. Smoking prevalence and attributable disease burden in 195 countries and territories, 1990-2015: a systematic analysis from the Global Burden of Disease Study 2015. Lancet 2017; 389 (10082): 1885-1906.

182. World Health Organization. WHO report on the global tobacco epidemic 2017. Monitoring tobacco use and prevention policies. MPOWER. WHO, Geneva 2017.

183. Herbeć A, Janik-Koncewicz K, McEwen A, et al. Development and evaluation of STAR - an expert digital platform supporting training and delivery of cessation interventions by healthcare professionals in Poland - Project overview. J Health Inequal 2017; 3 (2): 133-137.

184. Yeh CY, Schafferer C, Lee JM, et al. The effects of a rise in cigarette price on cigarette consumption, tobacco taxation revenues, and of smoking-related deaths in 28 EU countriesapplying threshold regression modelling. BMC Public Health 2017; 17: 676

185. Zatoński WA, Zatoński M, Janik-Koncewicz K, et al. Hundred years of cigarette smoking in Poland: three phases of the tobacco epidemic. J Health Inequal 2017; 3 (2): 118-122.

186. Kyriakos CN, Filippidis FT, Hitchman S, et al. Characteristics and correlates of electronic cigarette product attributes and undesirable events during e-cigarette use in six countries of the EUREST-PLUS ITC Europe Surveys. Tob Ind Dis 2018; 16 (Suppl 2): A1.

187. Vardavas CI, Bécuwe N, Demjén T, et al. Study protocol of EUREST-PLUS - European Regulatory Science on Tobacco: Policy Implementation to Reduce Lung Disease. Tob Ind Dis 2018; 16 (Suppl 2): A2.

188. Fong GT, Thompson ME, Boudreau C, et al. The Conceptual Model and Methods of Wave 1 (2016) of the EUREST-PLUS ITC 6 European Countries Survey. Tob Ind Dis 2018; 16 (Suppl 2): A3.

189. Zatoński M, Herbeć A, Zatoński WA, et al. Characterising smokers of menthol and flavoured cigarettes, their attitudes towards tobacco regulation, and the anticipated impact of the Tobacco Products Directive on their smoking and quitting behaviours: The EUREST-PLUS ITC Europe Surveys. Tob Ind Dis 2018; 16 (Suppl 2): A4.

190. Nogueira SO, McNeill A, Fu M, et al. Impact of anti-smoking advertising on health-risk knowledge and quit attempts across 6 European countries from the EUREST-PLUS ITC Europe Survey. Tob Ind Dis 2018; 16 (Suppl 2): A5.
191. Hummel K, Nagelhout GE, Fong GT, et al. Quitting activity and use of cessation assistance reported by smokers in eight European countries: Findings from the EUREST-PLUS ITC Europe Surveys. Tob Ind Dis 2018; 16 (Suppl 2): A6.

192. Kahnert S, Demjén T, Tountas Y, et al. Extent and correlates of self-reported exposure to tobacco advertising, promotion and sponsorship in smokers: Findings from the EUREST-PLUS ITC Europe Surveys. Tob Ind Dis 2018; 16 (Suppl 2): A7.

193. Fu M, Castellano Y, Tigova O, et al. Prevalence and correlates of different smoking bans in homes and cars among smokers in 6 Countries of the EUREST-PLUS ITC Europe Surveys. Tob Ind Dis 2018; 16 (Suppl 2): A8.

194. Petroulia I, Kyriakos CN, Papadakis S, et al. Patterns of tobacco use, quit attempts, readiness to quit and self-efficacy among smokers with anxiety or depression: Findings among six countries of the EUREST-PLUS ITC Europe Surveys. Tob Ind Dis 2018; 16 (Suppl 2): A9.

195. Trofor AC, Papadakis S, Lotrean LM, et al. Knowledge of the health risks of smoking and impact of cigarette warning labels among tobacco users in six European countries: Findings from the EUREST-PLUS ITC Europe Surveys. Tob Ind Dis 2018; 16 (Suppl 2): A10.

196. Tigova O, Amalia B, Castellano Y, et al. Secondhand exposure to e-cigarette aerosols among smokers: A cross-sectional study in six European countries of the EUREST-PLUS ITC Europe Surveys. Tob Ind Dis 2018; 16 (Suppl 2): A11.

197. Nogueira SO, Tigova O, Castellano Y, et al. Cigarette brand loyalty among smokers in six European countries: Findings from the EUREST-PLUS ITC Europe Surveys. Tob Ind Dis 2018; 16 (Suppl 2): A12.

198. Driezen P, Thompson ME, Fong GT, et al. Cross-border purchasing of cigarettes among smokers in Six Countries of the EUREST-PLUS ITC Europe Surveys. Tob Ind Dis 2018; 16 (Suppl 2): A13.

199. Hedman L, Katsaounou PA, Filippidis FT, et al. Receiving support to quit smoking and quit attempts among smokers with and without smoking related diseases: Findings from the EUREST-PLUS ITC Europe Surveys. Tob Ind Dis 2018; 16 (Suppl 2): A14

200. East KA, Hitchman SC, McDermott M, et al. Social norms towards smoking and electronic cigarettes among adult smokers in seven European Countries: Findings from the EUREST-PLUS ITC Europe Surveys. Tob Ind Dis 2018; 16 (Suppl 2): A15.

201. Demjén T, Kiss J, Kovács PA, et al. The purchase sources of and price paid for cigarettes in six European countries: Findings from the EUREST-PLUS ITC Europe Surveys. Tob Ind Dis 2018; 16 (Suppl 2): A16.

202. Fu M, Castellano Y, Tigova O, et al. Correlates of the support for smoke-free policies among smokers: A cross-sectional study in six European countries of the EUREST-PLUS ITC EUROPE SURVEYS. Tob Ind Dis 2018; 16 (Suppl 2): A17.

203. Fu M, Castellano Y, Tigova O, et al. Smoking in public places in six European countries: Findings from the EUREST-PLUS ITC Europe Survey. Tob Ind Dis 2018; 16 (Suppl 2): A18. 
204. Vardavas CI, Bécuwe N, Demjén T, et al. Evaluating the European Union (EU) Tobacco Products Directive: Findings from the EUREST-PLUS ITC cohort study among six EU Member States (MS). Tob Ind Dis 2018; 16 (Suppl 3): A42.

205. Kyriakos CN, Filippidis FT, Hitchman S, et al. Undesirable events during electronic cigarette use prior to the implementation of Article 20 of the European Union Tobacco Products Directive: Findings from the EUREST-PLUS ITC Europe Surveys. Tob Ind Dis 2018; 16 (Suppl 3): A44.

206. Petroulia I, Kyriakos CN, Papadakis S, et al. Quitting behaviors and cessation assistance used among smokers with anxiety or depression: Findings among six countries of the EUREST-PLUS ITC Europe Surveys. Tob Ind Dis 2018; 16 (Suppl 3): A45.

207. Przewoźniak K, Zatoński M, Herbeć A, et al. Characterizing smoking, cessation behaviours and attitudes toward tobacco control policies among smokers of menthol and flavored cigarettes: the EUREST-PLUS ITC Europe Surveys. Tob Prev Cessation 2019; 5 (Suppl): A11.

208. Kyriakos CN, Driezen P, GirvalakiC, et al. Awareness of changes to tobacco product content and packaging design after implementation of the EU Tobacco Products Directive among smokers: Findings from the EUREST-PLUS ITC Europe Surveys. Tob Prev Cessation 2019; 5 (Suppl): A94.

209. Przewoźniak K, Zatoński M, Herbeć A, et al. Attitudes towards tobacco control policies among smokers of menthol, other flavored and unflavored cigarettes: Findings from the EUREST-PLUS ITC Europe Surveys. Tob Induc Dis 2019; 17 (Suppl 1): A47.

210. Połtyn-Zaradna K, Zatońska K, Basiak A, et al. Sociodemographic characteristic of changes in smoking patterns in rural and urban population of PURE Poland study: findings from 6-year follow up. BMC Public Health 2019; 19 (6): 9.

211. Wiraszka G, Obierzyńska A. Poziom uzależnienia od nikotyny oraz motywacja do zaprzestania palenia tytoniu wśród młodych dorosłych - studentów regionu świętokrzyskiego [Level of nicotine addiction and motivation to stop smoking among young adults - students of Świętokrzyskie region]. Piel Zdr Publ 2019; 9 (1): 15-22.

212. Zatoński MZ. State, society, and the politics of smoking in Poland, during and after communism (1960-2000). PhD thesis. London School of Hygiene \& Tropical Medicine, London 2019.

213. Filippidis FT, Driezen P, Kyriakos CN, et al. Transitions from and to roll-your-own tobacco, perceptions and health beliefs among smokers: findings from the EUREST-PLUS ITC Europe Surveys. Eur J Public Health 2020; 30 (Suppl 3): iii18iii25.

214. Gravely S, Driezen P, Kyriakos CN, et al. European adult smokers' perceptions of the harmfulness of e-cigarettes relative to combustible cigarettes: cohort findings from the 2016 and 2018 EUREST-PLUS ITC Europe Surveys. Eur J Public Health 2020; 30 (Suppl 3): iii38-iii45.

215. Thompson ME, Driezen P, Boudreau C, et al. Methods of the International Tobacco Control (ITC) EUREST-PLUS ITC Europe Surveys. Eur J Public Health 2020: 30 (Suppl 3): iii4-iii9.
216. Vardavas CI, Kyriakos CN, McNeill A, et al. Evaluating the impact of the Tobacco Products Directive within the context of the FCTC in Europe - findings from the EUREST-PLUS ITC Europe Surveys: introductory Commentary. Eur J Public Health 2020; 30 (Suppl 3): iiil-iii3.

217. Vardavas CI, Kyriakos CN, Driezen P, et al. Transitions in product use during the implementation of the European Tobacco Products Directive: cohort study findings from the EUREST-PLUS ITC Europe Surveys. Eur J Public Health 2020; 30 (Suppl 3): iii10-iiil7.

218. Papadakis S, Katsaounou P, Kyriakos CN, et al. Quitting behaviours and cessation methods used in eight European Countries in 2018: findings from the EUREST-PLUS ITC Europe Surveys. Eur J Public Health 2020; 30 (Suppl 3): iii26iii33.

219. Zatoński M, Herbeć A, Zatoński W, et al. Cessation behaviours among smokers of menthol and flavoured cigarettes following the implementation of the EU Tobacco Products Directive: findings from the EUREST-PLUS ITC Europe Surveys. Eur J Public Health 2020; 30 (Suppl 3): iii34-iii37.

220. McDermott MS, East KA, Hitchman SC, et al. Social norms for e-cigarettes and smoking: associations with initiation of e-cigarette use, intentions to quit smoking and quit attempts: findings from the EUREST-PLUS ITC Europe Surveys. Eur J Public Health 2020; 30 (Suppl 3): iii4-iii54.

221. Kahnert S, Driezen P, Balmford J, et al. Impact of the Tobacco Products Directive on self-reported exposure to e-cigarette advertising, promotion and sponsorship in smokers - findings from the EUREST-PLUS ITC Europe Surveys. Eur J Public Health 2020; 30 (Suppl 3): iii55-iii61.

222. Nikitara K, Girvalaki C, Kyriakos CN, et al. Changes in electronic cigarette use and label awareness among smokers before and after the European Tobacco Products Directive implementation in six European countries: findings from the EUREST-PLUS ITC Europe Surveys. Eur J Public Health 2020; 30 (Suppl 3): iii62-iii67.

223. Chung-Hall J, Fong GT, Meng G, et al. Support for e-cigarette policies among smokers in seven European countries: longitudinal findings from the 2016-18 EUREST-PLUS ITC Europe Surveys. Eur J Public Health 2020; 30 (Suppl 3): iii68-iii77.

224. Lotrean LM, Trofor A, Radu-Loghin C, et al. Awareness and use of heated tobacco products among adult smokers in six European countries: findings from the EUREST-PLUS ITC Europe Surveys. Eur J Public Health 2020; 30 (Suppl 3): iii78-iii83.

225. Kahnert S, DriezenP, BalmfordJ, et al. Effectiveness of tobacco warning labels before and after implementation of the European Tobacco Products Directive - findings from the longitudinal EUREST-PLUS ITC Europe surveys. Eur J Public Health 2020; 30 (Suppl 3): iii84-iii90.

226. Aleyan S, Driezen P, McNeill A, et al. Evaluating the impact of introducing standardized packaging with larger health-warning labels in England: findings from adult smokers within the EUREST-PLUS ITC Europe Surveys. Eur J Public Health 2020; 30 (Suppl 3): iii91-iii97. 
227. Kyriakos CN, Driezen P, GirvalakiC, et al. Implementation of the European Tobacco Products Directive: findings from the EUREST-PLUS ITC Europe Surveys. Eur J Public Health 2020; 30 (Suppl 3): iii98-iii107.

228. Nogueira SO, Tigova O, Driezen P, et al. Do smokers want to protect non-smokers from the harms of second-hand smoke in cars? Findings from the EUREST-PLUS ITC Europe Surveys. Eur J Public Health 2020; 30 (Suppl 3): iii108-iii112.

229. Girvalaki C, Filippidis FT, Kyriakos CN, et al. Perceptions, predictors of and motivation for quitting among smokers from six European countries from 2016 to 2018: findings from EUREST-PLUS ITC Europe Surveys. Int J Environ Res Public Health 2020; 17 (17): 6263.

230. Połtyn-Zaradna K, Sozańska B, Basiak-Rasała A, et al. Spirometry parameters in smokers and non-smokers with and without respiratory symptoms in the PURE Poland Study population. J Health Inequal 2020; 6 (1): 21-26. 